This is an electronic reprint of the original article. This reprint may differ from the original in pagination and typographic detail.

Author(s): Ojala, Arto; Tyrväinen, Pasi

Title: $\quad$ Business Models and Market Entry Mode Choice of Small Software Firms

Year: $\quad 2006$

Version:

Please cite the original version:

Ojala, A., \& Tyrväinen, P. (2006). Business Models and Market Entry Mode Choice of Small Software Firms. Journal of International Entrepreneurship, 4(2-3), 69-81. https://doi.org/10.1007/s10843-006-0001-z

All material supplied via JYX is protected by copyright and other intellectual property rights, and duplication or sale of all or part of any of the repository collections is not permitted, except that material may be duplicated by you for your research use or educational purposes in electronic or print form. You must obtain permission for any other use. Electronic or print copies may not be offered, whether for sale or otherwise to anyone who is not an authorised user. 


\title{
Business Models and Market Entry Mode Choice of Small Software Firms
}

\author{
Arto Ojala and Pasi Tyrväinen \\ University of Jyväskylä
}

\begin{abstract}
So far the critical choice of the entry mode for a target country has been examined ignoring the special features of firms. Particularly, the impact of the wide variation of business models of software firms has been ignored. This multi-case study investigates the relation between the business model and the entry mode of eight software firms. The results imply that the product strategy and the service and implementation model of a software firm are closely connected to the entry mode choice, while the distribution model of intangible software products does not seem to have impact on the operation mode.
\end{abstract}

Keywords: entry mode, market entry, business models, software, small firms

\section{Introduction}

Choosing the right entry mode for a target country is a critical managerial decision and affects the long term success of a firm (Bradley and Gannon, 2000; Brouthers et al., 1996; Lu and Beamish, 2001; Luostarinen and Welch, 1997). In existing literature, various scholars have examined reasons behind entry mode selection. Studies in the field of international entrepreneurship have mainly examined software firms' entry mode choice by using the network approach (Bell, 1995, 1997; Coviello and Munro, 1997; Moen et al., 2004), the eclectic theory (Brouthers et al., 1996), the transaction cost analysis (McNaughton, 1996) or a firm's strategy (Brouthers, 1995; Brouthers and Van de Kruis, 1997). These studies have generally described small software firms as a homogeneous group, whereas very little attention has been targeted to how various types of software firms (Hoch et al., 2000; Kontio et al., 2005; Rajala et al., 2003a) choose their entry mode for foreign operations. In addition, economic theories and models (see e.g. Buckley and Casson, 1981; Dunning, 1988; Johanson and Vahlne, 1977; Luostarinen, 1979; Williamson, 1985) have mostly focused on macro level factors behind the choice of entry mode, whereas particular characteristics of a firm's business have received less attention.

In the high technology sector, the term business model has been used to describe how various types of firms' execute their business activities (Currie, 2004; Kontio et al., 2005; Mahadevan, 2000; Rajala et al., 2003a, 2003b, 2004; Zeng and Reinartz, 2003). Although the term business model is ambiguous and researchers have proposed different definitions for it, an increasing number of studies in various academic fields have appeared on how firms implement their business models (Tikkanen et al., 2005). In general, the business model defines who the customers are, what they value, and how this value can be delivered to the customers (Magretta, 2002). Despite the growing amount of studies related to various business models, almost no research has been done on connections between a firm's business model and the choice of entry mode. This is surprising if we take into consideration some commonly cited research findings in the literature of international entrepreneurship. These findings suggest that the nature of a firm's business (Jones, 1999), characteristics of a product (Bell, 1995, 1997), requirements for customer support (Burgel and Murray, 2000), and customization needs (McNaughton, 1996) are connected 
to a firm's entry mode selection. Brouthers et al. (1996) also suggest that more research is needed to investigate how the intangibility of the software products affects the choice of entry mode.

For the aforementioned reasons, we are trying to fill this gap between business models and entry mode choice by combining literature related to technology entrepreneurship, international business, and business models. In addition, we conduct an empirical multi-case study to find how the business model of a small software firm affects the choice of entry mode. A firm's business model is used as a tool to analyze the nature of a firm. This helps us find similarities between firms that are using a certain business model and selected entry mode to operate in the market.

This paper proceeds as follows: literature related to entry mode choice and business models are reviewed first. The research questions related to the business models are derived from the literature. Then the research method applied in this study is described. After that the findings from eight case firms are presented, followed by discussion and conclusions. Finally, the last section draws a summary of the research and suggests some directions for future research.

\section{Literature Review}

The study of Brouthers and Nakos (2004) focused on a transaction cost theory in SMEs' entry mode choice. They found that SMEs with greater asset-specific investments preferred equity modes whereas less asset-specific investments were handled through non-equity modes. Their findings also reveal that environmental uncertainties are connected to the use of non-equity entry modes. This supports earlier findings of Brouthers (1995) which suggested that software firms perceiving higher international risk favored non-equity entry modes. McNaughton (1996) used the transaction cost theory to investigate Canadian software firms' channel integration decisions. Findings in his study adduced that channel volume, asset specificity, volatility, and requirements for product customization were important determinants for the choice of entry mode.

Brouthers et al. (1996) investigated the impacts of ownership and location advantage in small and medium-sized software firms' entry mode choice by using Dunning's (1988) eclectic theory. They found that a firm's ownership and location advantages affect the choice of firms entry mode. Firms that had a high ownership or location advantage preferred more integrated entry modes such as sales subsidiaries. A later study of Nakos and Brouthers (2002) related to entry mode choice of SMEs also supported these findings. Their research suggested that firms with differentiated products preferred equity entry modes, as well as firms that were entering to markets whit high potential. Both of these studies also supported Dunning's eclectic theory.

The Uppsala internationalization model (Johanson and Wiedersheim-Paul, 1975; Johanson and Vahlne, 1977) suggests that the choice of entry mode depends on a firm's experience in international markets. The model presents internationalization as a stepwise progressive model where a firm starts irregular exporting to the target country and, over the time when the firm gathers more experience, it starts exporting via independent representatives, establishes a sales subsidiary and finally starts own production in the target country. The choice of entry mode is seen as a learning process and increasing commitment to the market. This "stage" model of entry mode selection has later been challenged in many studies related to international entrepreneurship (Bell, 1995; Crick and Spence, 2005; Jones, 1999; Moen et al., 2004).

The Network approach (Johanson and Mattsson, 1988) has been used to examine small software firms' entry mode selection (Bell, 1995; Coviello and Munro, 1997; Moen et al., 2004). The findings of Coviello and Munro (1997) implied that the choice of entry mode depended on firms' formal and informal network relationships which evolved over time. By using these network relationships, small software firms first established product development agreements 
with larger hardware firms. After that they started direct sales or distribution to market in psychical proximity and finally established joint marketing or development agreements, joint ventures, or sales offices to psychically distant markets. In addition, firms used distributors, piggy-backing, and direct sales. These findings have also been supported by the study of Moen et al. (2004) related to small software firms' internationalization.

\section{Business Models of Software Firms}

The concept of business model has been widely used in the literature of e-commerce, management, and business since last decade and it has a number of definitions. Magretta (2002) defined the business model as a definition of how a firm works, who its customers are, what the customers value, how a firm makes money, and how value can be delivered to customers costeffectively. Currie (2004) presented a conceptual framework of an application service provider ebusiness model that includes strategic positioning, product/service portfolio, and value proposition for value creation. Mahadevan (2000) divided business models in e-commerce into value streams, revenue streams, and logistic streams. The value stream identifies the expected value for various groups in the business interaction. The revenue stream is a plan describing how business will generate revenue and the logistical stream includes the design of the supply chain. In their study, Tikkanen et al. (2005) presented the business model as a cognitive phenomena and the material aspect of a firm. The material aspect includes a firm's network of relationships, strategy and structure, operations, and finance and accounting.

We selected the framework of Rajala et al. (2003a, 2003b, 2004) for this research because it has been developed particularly for analyzing business models in software firms. This model is motivated by observations suggesting that software firms' business models differ from those of other types of firms due to, for instance, the intangible nature of software products and short product life-cycles. For software firms it is also important to be able to respond to fast changes and requirements in target markets. The framework (Rajala et al., 2003a, 2003b, 2004) divides a business model into product strategy, revenue logic, distribution model, and service and implementation model. In this study, we use these four elements for analyzing connections between a firm's business model and entry model.

Firstly, product strategy describes a firm's core product offering. It focuses on product development and the way this work is organized. The product strategy can vary from customer specific software solutions to the development of highly standardized software products. In their book, Hoch et al. (2000) divided software firms into three groups depending on the productization level of a firm's product offering. In their categories, professional service firms have the lowest level of productization and their products are custom-made software solutions for each customer. Enterprise solution firms offer software products for business users. These products have core software that is customized for various customer segments. Mass-market software firms have the highest level of productization and their products are mainly targeted to consumer markets. In his studies, related to small software firms' internationalization, Bell (1995, 1997) discovered evidence on the connections between the characteristics of a firm's products and the entry mode that firms used in foreign markets. Software firms that were in the solution consultant or product tailoring business used their own export sales staff in dealing with endusers, whereas software firms in standard product business chose agents or distributors to handle the market. The research results of McNaughton (1996) also revealed that customization of software products was linked to a firm's entry mode choice. 
Question 1: Is the product strategy of a software firm connected to the choice of entry mode?

Secondly, revenue logic describes the source of profits that a firm generates by selling its software products and related services. Software products have a very high initial cost, whereas reproduction costs can be nearly nonexistent. This makes pricing strategies of software products fairly different than those in other industries (Bakos and Brynjolfsson, 1999; Mahadevan, 2000). Low reproduction cost and the intangible nature of software enables various pricing models for software firms, such as effort based pricing, licensing, revenue sharing, and combinations of these (Rajala et al., 2003). If software products are available in the Internet through online servers, a firm can use connect-time-based pricing, search-based pricing or subscription-fee pricing to sell their products to customers (Jain and Kannan, 2002).

Question 2: Is the revenue logic of a software firm connected to the choice of entry mode?

Thirdly, the distribution model describes channels that a firm uses for marketing and selling its products and services to the end users. The distribution model also characterizes the sales process and its outcomes. The model can vary from direct sales to decentralized distribution (Rajala et al., 2003a, 2004) independently from the entry mode. In direct sales a firm's unit in the host country sells its products directly to customers without using distributors, whereas in the decartelized distribution model a firm might have one or several firms distributing their products. The study of Coviello and Munro (1997) suggested that software firms use joint marketing or development agreements, joint ventures, sales offices, distributors, piggy-backing, and direct sales to handle foreign customers. Studies of Bell $(1995,1997)$ revealed that software firms use direct sales through their own units, indirect export, agents, and distributors when they market and deliver their products to customers.

Question 3: Is the distribution model of a software firm connected to the choice of entry mode?

Fourthly, the services and implementation model describes how the product will be installed, implemented, maintained, and supported. Depending on the software products, a customer can execute all or most of these phases as self-service, and in some cases a firm's unit in the host country executes all of these phases for a customer. The third option is that a partner, such as a distributor or a system integrator, takes care of these responsibilities. Thus, the service and implementation model can vary from custom-specific system work and system integrated projects to self-service by the client (Rajala et al., 2003a). Hoch et al. (2000) presented that the degree of a software productization is connected to the amount of required installation and aftersales services. If a software product has a low level of productization, it requires intensive consulting, support, and maintenance, whereas highly productized mass-market software products are complete solutions that customers can install and use without additional support. Bell (1995) found that the level of complexity of the software product was linked to the market entry strategy. If a software product was complex and required extensive installation, training, upgrading, and after-sales services, it led to close relationships between a software firm and a customer. Also the findings of Burgel and Murray (2000) revealed that requirements for customer support are connected to the chosen operation mode in high technology industries. 
Question 4: Is the service and implementation model of a software firm connected to the choice of entry mode?

\section{Research Method}

We selected the case study method for this study due to the explanatory nature of the research. The case study method enables explaining the significance and cause-and-effect relationships of the phenomena under the investigation (Yin, 1994). We followed the guidelines proposed by Eisenhardt (1989) by staying as close as possible to the no theory and no hypotheses origin in the research process. The data analysis in this study was executed by using the following steps: 1) data reduction, 2) data display, and 3) drawing conclusions and verification (Miles and Huberman, 1994; Yin, 1994) to identify and match relevant patterns of the business model and compare those with the entry mode of the case firms.

The case firms selected followed certain criteria: the firms a) had headquarters in Finland, b) operated in the Japanese market, c) did business in the field of software, and d) had a maximum of 500 employees worldwide. Since Finland is a small and open economy with a very limited domestic market, Finnish software firms have to internationalize their business successfully if they want to acquire more customer base. Japan was selected as the target country for two reasons. Firstly, Japan is the second largest market for software products, but also a very challenging country to do successful business in as mentioned in several studies (see e.g. Czinkota and Kotabe, 2000). Secondly, choosing Finnish software firms in Japan enabled addressing the target group to a large extent by using a qualitative case study method. Suitable firms for this study were identified by using websites of the Finnish Chamber of Commerce in Japan and the Finnish Software Business Cluster, as well as a list of firms in the publication "Software Product Business Cluster in Finland 2005". By using these sources altogether nine suitable firms were identified. These firms were contacted with an e-mail request to attend the research. Eight of the nine firms answered and were willing to share their knowledge and experience of the Japanese market.

The semi-structured open-ended interviews were conducted with a total of 16 managers in firms' headquarters in Finland and in their units in Japan. All executives (including the following titles: CTO, Director, Executive Vice President, President, Managing Director, Sales Administrator) interviewed had an in-depth knowledge of their firms' business models and operations in the target country. The 60-90 minute-long interviews were digitally recorded, carefully listened to, and transcribed verbatim by using a word processor. A second listening was performed to ensure correspondence between the recorded and transcribed data. Complete case reports were sent back to the interviewees to ensure the validity and authenticity of the collected data. If interviewees in the case firms found some inaccuracies in the text, these were corrected based on their comments. In addition, some telephone and e-mail interviews were used to collect further information from the interviewees. The collected data was also compared with other sources, such as websites and annual reports of the case firms.

\section{Research Findings}

In order to give a clearer description of the firms' business model and due to space limitations, the findings are presented by grouping together the firms that applied similar elements of the business model rather than describing each individual case separately. Table 1 gives an overview of the case firms. 
Table 1 Key information of the case firms

\begin{tabular}{lcccl}
\hline & $\begin{array}{c}\text { Number of } \\
\text { employees } \\
\text { worldwide }\end{array}$ & $\begin{array}{c}\text { Years of } \\
\text { operation in } \\
\text { Japan }\end{array}$ & $\begin{array}{c}\text { Mode of the } \\
\text { business in } \\
\text { Japan }\end{array}$ & \multicolumn{1}{c}{$\begin{array}{c}\text { Entry mode in the } \\
\text { Japanese market }\end{array}$} \\
\hline Firm A & 30 & 4 & B to B & Representative \\
Firm B & 90 & 4 & B to B & Representative office \\
Firm C & 300 & 6 & B to B & Sales subsidiary \\
Firm D & 240 & 6 & B to B & Sales subsidiary \\
Firm E & 100 & 6 & B to B & Sales subsidiary \\
Firm F & 210 & 5 & B to B & Sales subsidiary \\
Firm G & 12 & 7 & B to C & Joint venture \\
Firm H & 35 & 3 & B to C & Corporate \\
\hline
\end{tabular}

The average number of employees in the case firms was 127. Firms had operated in the Japanese market from three to seven years by using direct business operations. Six of the firms sold their main products to other companies (B to B) and two were in consumer markets (B to C). Four of the case firms used a sales subsidiary as the entry mode into the market. Firm $A$ had a representative who worked within their Japanese distributor and firm B had a representative office in the market. Firm $\mathrm{H}$ penetrated into the Japanese market by selling their shareholding to a Japanese corporation; the firm was still headquartered in Finland and operated as an independent unit of the corporation. Firm $\mathrm{G}$ used a joint venture with its Japanese partners. Later on in this study we will use the term 'cooperative entry modes' to describe the entry modes of firms G and $\mathrm{H}$. It should also be noted that firms $\mathrm{E}$ and $\mathrm{F}$ have only Japanese personnel in their units in Japan.

\section{Product Strategy}

The product strategy of firms A and B focused on tailor-made software solutions. Their product offering included a core product that was customized according to each customer's requirements. Firm A developed virtual design environments for electronics intensive products, such as mobile phones and consumer electronics. The product strategy of Firm B focused on the development of video codecs for handheld devices. Customization of the products of firms A and B required close cooperation with clients to specify requirements for software solutions which will operate in a customer's environment.

The product strategies of firms C, D, E, and F concentrated on enterprise solutions. They had core products which were customized with minor changes for various customer segments. Firm C developed structural building and modeling software for the construction industry. Their products were highly productized, but required some tailoring due to customers' needs and different regulations in the Japanese building industry. Firm D's product strategy concentrated on enterprise level network protection and business continuity assurance software for large-sized companies. The firm's products were highly productized and sold only with minor changes to different customer segments. Firm E focused on enterprise and communications security solution software for large-sized firms. Their core products were highly productized, but required localization and customization to various markets, such as localizing the user interface for a target country. The main products in firm F's product strategy were tools which can be used to analyze and simulate mobile and Internet networks. Their products consisted mainly of software, 
but also included some hardware components with software. Firm F's products were highly productized, and required only minor customization.

Firms $\mathrm{G}$ and $\mathrm{H}$ developed mass-market products for consumer markets in Japan. These products were highly productized and sold without any modifications to consumers. Firm G's product strategy focused on a mobile game for the consumer market. Firm H sold licensed video games through broadband networks to consumers. Firms $\mathrm{G}$ and $\mathrm{H}$ had also have developed platforms that they used to deliver the content, but their main products in Japan were massmarket products.

\section{Revenue Logic}

Firm A's revenue consisted of license fees, maintenance fees, and revenues from joint projects with a distributor. The license fee depended on the number of computers where customers used the software. The maintenance fee was optional and included new product updates and after-sales support services. Firm A also had joint projects with distributors for developing customized products from A's core product. Income from these projects depended on how much labor time was used in the project.

Firm B's revenue consisted of license fees, royalties per sold device, and maintenance fees. When firm B made a contract with a customer, they got a license fee and when the customer launched mass-production, firm B got royalties per sold device. They also had a voluntary annual maintenance fee for customers, which depended on customers' support needs and included, for instance, new product updates.

The revenue logic of firms $\mathrm{C}, \mathrm{D}, \mathrm{E}$, and $\mathrm{F}$ was similar. The revenue consisted of license fees and annual maintenance fees. The license fee depended on the number of computers where the software was used. The maintenance fee was optional in all cases, but was usually an important part of the product. New product updates and after-sales support services were included in the maintenance fee.

Firms $\mathrm{G}$ and $\mathrm{H}$ used a revenue based model which was grounded on the number of players as well as revenue sharing with partners. Firm $\mathrm{H}$ that sold video games through broadband networks also had various pricing models, such as pay-per-play and time-based charges. Revenue was shared with the content owner, the internet portal, and firm $\mathrm{H}$. In the case of G, the revenue was shared with a TV station that advertises a game and telecom operators who delivered games to mobile phones.

\section{Distribution Model}

Firms $\mathrm{B}$ and $\mathrm{H}$ used direct sales without distributors to deliver their products to the end users. Firm B used personal selling because their products required intensive cooperation with customers using the sales process. They had also tried to find a suitable distributor channel to handle the sales process, but due to the complexity of the products, the demanding sales process, and a long sales cycle they had not found a suitable distributor. Firm $\mathrm{H}$ used direct sales to consumers through broadband networks. Customers logged into a portal where they selected a game and a method of payment. The selected game itself was not sent to the customer's computer. The player only got an interface to a game and the game itself was running in the firm's server.

Although firms D, E, and $G$ had units of their own in Japan, they used distributors for delivering their products to customers. In firms D and E there were two reasons for this choice. Firstly, using local distribution channels gave better possibilities for attaining potential customers 
in the market. Secondly, it was a strategic decision to avoid competition with a distributor in the market area. Firm $G$ who sold mobile games had no other options than using telecom operators for distributing their mobile games to customers.

Firms A, C, and F used both direct selling and distributors in the market. Firm A used a distributor to deliver products which required a joint delivery project with the distributor, customer and firm A. These products were highly customized according to the customers' specifications. Direct sales were used with products that were functionally close to their core products and did not require intensive customization. Firms $\mathrm{C}$ and $\mathrm{F}$ sold their products directly and through a distributor to the end users. This could easily cause a competitive situation between the firm and a distributor but using both of these channels gave good possibilities for attaining potential customers.

Services and Implementation Model

In cases $\mathrm{A}$ and $\mathrm{B}$, customers were supported by the headquarters and by using their representatives in the market. Firm A's representative and distributor in Japan gave after-sales and implementation support as well as training to customers that were handled through the distributor. Their direct customers were mainly supported by the headquarters. Firm B's representative in Japan and the headquarters gave installation and technical support to customers in the market. Depending on the customization level of their products, the implementation phase took from a couple of days up to three months.

Firms D and E applied their service and implementation model as follows: distributors supported the end users and units of D and $\mathrm{E}$ in Japan gave secondary support to the distributors. In case $\mathrm{D}$, distributors were selected based on their capability to handle all after-sales service and implementation assignments with the customers. The role of firm D's unit in Japan was to give support and training to their distributors. Firm E had a similar model with firm D, but in some special cases they also gave after-sales and implementation support from the headquarters straight to the end users.

Firms $\mathrm{C}$ and $\mathrm{F}$ had quite similar services and implementation models. Firm C's unit in Japan offered support to their own customers and the distributor supported their own customers. In cases where the distributor was incapable to give support, the responsibility shifted to firm C's unit in Japan. Firm F had two distributors in the Japanese market. One of the distributors was capable of handling services and implementation on its own, whereas the other only handled the sales and firm F's unit in Japan supported their customers along with firm F's direct customers in the market.

Firm G's unit in Japan gave maintenance support to their distributors who delivered G's mobile games to the consumers. In the case of $\mathrm{H}$, who delivered video games to consumers through broadband networks, the consumers received support from the firm's development unit located in Finland.

Table 2 summarizes case findings and presents the used entry mode of the firms. 


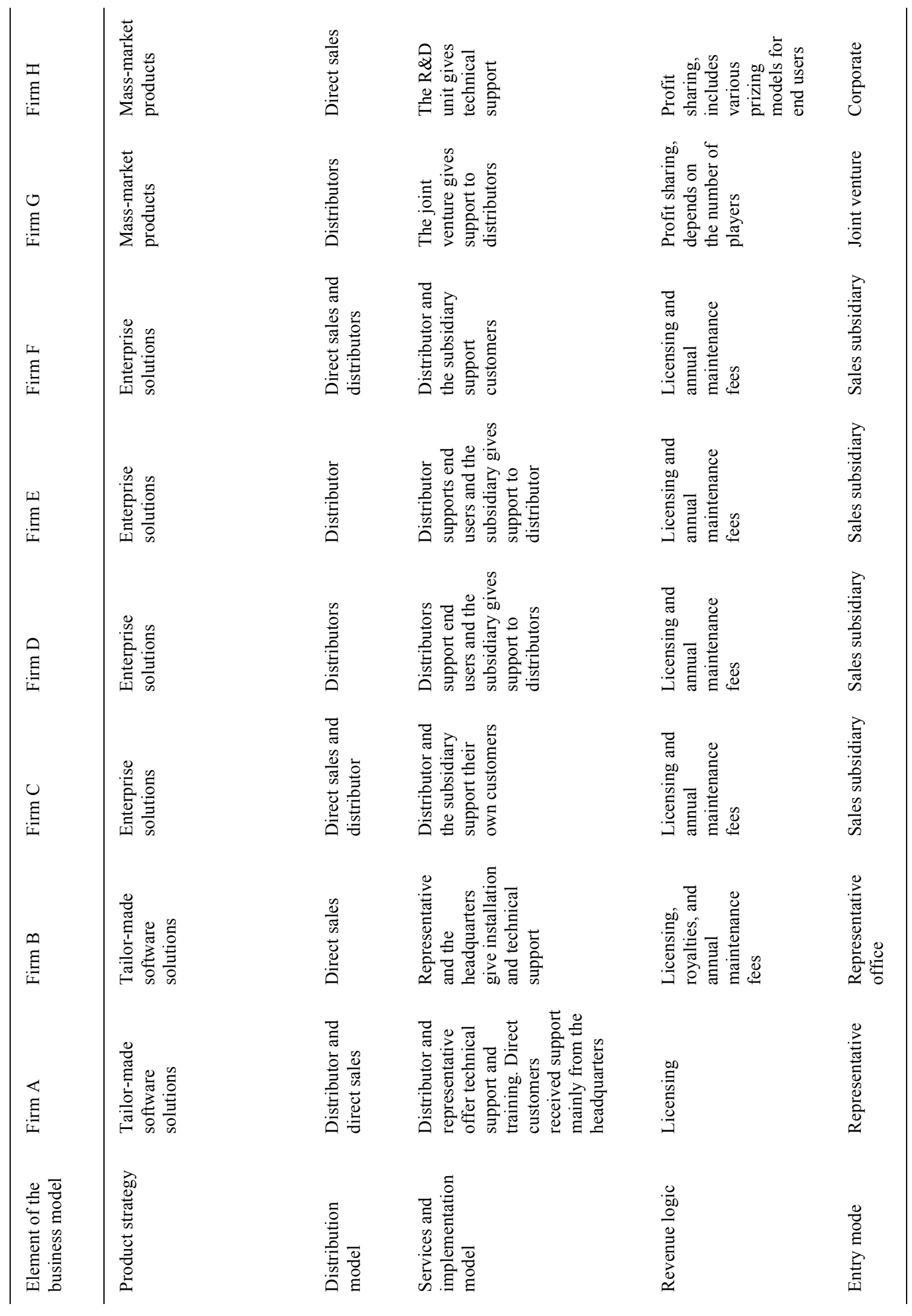


Table 2 Summary of the business models of the case firms and the selected entry mode in the Japanese market.

\section{Discussion and Conclusions}

Findings obtained from the eight case firms give a clear answer to the first question. The product strategy of a software firm has a strong connection to the selected entry mode to operate in the market. Firstly, case firms A and B, which tailored their products in close cooperation with customers, used representatives as the entry mode in the target country. This was mainly due to complex products that required strict specification of the product with customers. In addition, due to the niche markets for their products, they were able to handle the customers in the market without investments to a subsidiary. Secondly, the case firms C, D, E, and F, which had a core product that was customized or localized on the grounds of customer needs, used a sales subsidiary entry mode. The sales subsidiary enabled after sales support and marketing by using local personnel. Thirdly, case firms $\mathrm{G}$ and $\mathrm{H}$, who offered mass-market products for consumer markets, used cooperative entry modes that enabled the use of local knowledge. The main reason for these cooperative operation modes was the high level of localization requirements for software products that were targeted to the consumer markets in Japan.

Research findings reveal that the revenue logic of the studied software firms had some connection to the entry mode chosen (Question 2). Six of the firms (A, B, C, D, E, and F) used revenue logic that consisted of license and maintenance fees. In addition, firms $A$ and $B$ that used a representative in the market had revenue from joint projects with a distributor and royalties respectively. Those firms $(\mathrm{C}, \mathrm{D}, \mathrm{E}$, and $\mathrm{F})$ that used a sales subsidiary in the market received revenues only from license and maintenance fees. Firms $\mathrm{G}$ and $\mathrm{H}$ used cooperative entry modes and their revenue logic based on the amount of users and revenue sharing with partners. Although there seem to be some connections between revenue logic and the choice of entry mode, the revenue logic still seems to relate more to the characteristics of a product than the selected entry mode.

The use of a certain distribution model does not seem to be connected to the choice of entry mode in the market (Question 3). Selecting the distribution model seems to be more related to a firm's strategic decision on how to deliver products to the end users than the selected entry mode in the market. For instance, firms B and $\mathrm{H}$ that both used direct sales to the end users were totally dissimilar in their product offering and selected entry mode.

Based on the research findings, the chosen service and implementation model of the case firms has some connection to the selection of entry mode in the market (Question 4). Firms A and $\mathrm{B}$ that used representatives in the market gave after sales and implementation support from the headquarters and using their representatives. Firm A also used a distributor that gave basic support to some of the end users. In firms that used a sales subsidiary operation mode $(C, D, E$, and F), the service and implementation model depended on their distribution model. Firms D and $\mathrm{E}$ that used only distributors in the market gave support mainly to the distributors who handled services and implementations for the end users. Firm $\mathrm{C}$ and $\mathrm{F}$ applied a divided services and implementations model in which a distributor mainly gave support to their own customers and their unit in Japan supported their direct customers. In firms $\mathrm{G}$ and $\mathrm{H}$ that used integrative entry modes, the connection to the service and implementation model was less obvious. Firm $\mathrm{G}$ used a similar two-line service and implementation model as firms D and E. There the secondary responsibility was given to the local unit which supported distributors who gave the primary 
support to the end users. Firm $\mathrm{H}$ that delivered its products directly to end users provided support from its development unit located in Finland.

\section{Summary and Further Research}

This paper investigated the connections between software firms' business models and the choice of entry mode. Business models were divided into product strategy, revenue logic, distribution model, and service and implementation model by using the framework of Rajala et al. (2003a, 2003b, 2004).

The connection between the product strategy and the selected entry mode to operate in the market was evident in these eight cases. The firms whose product strategy led to a close cooperation with customers used representatives in the market, whereas firms developing semistandardized enterprise solutions preferred sales subsidiaries of their own. Firms that offered mass-market products to consumers used cooperative entry modes (joint venture or corporate). These findings support earlier findings of Bell $(1995,1997)$ which suggest that the nature of a firm's product offering is connected to the entry mode that firms used in foreign markets.

Also the choice of the service and implementation model and the choice of entry mode were somewhat related. This is consistent with Bell's $(1995,1997)$ observation that the complexity of software products is connected to firms' market entry strategies. It also supports the findings of Burgel and Murray (2000) implying that requirements for customer support affect entry mode selection in high technology industries.

A relationship between revenue logic and the choice of entry mode was also visible in the case firms to some extent. However, service and implementation model and revenue logic seem to be closely associated to a firm's product offering and can be understood as a subset of the product strategy. A certain kind of product strategy seems to lead to the use of a particular revenue, service, and implementation model. No connections between the distribution model used and the entry mode selected were found in the case firms. Using distributors beside the firm's own unit or representative in the market seems to be the individual decision of a firm and not related to the selected entry mode.

The research findings of this study add some new insight to contemporary literature related to the choice of entry mode. Firstly, economic theories and models (see e.g. Buckley and Casson, 1981; Dunning, 1988; Johanson and Vahlne, 1977; Luostarinen, 1979; Williamson, 1985) that have been used to explain the reasons behind a firm's entry mode selection have mainly focused on macro level variables, such as environmental issues, whereas the special characteristics of a firm's business have received less attention. Recalling the small size of the case firms of this study, the results suggest that the product strategy of a firm is an important determinant of small software firms' entry mode choice. This also gives some support to findings of Crick and Spence (2005) suggesting that a single theory cannot fully explain internationalization behavior of high technology SMEs.

Secondly, the intangible nature of software products creates some challenges for internationalization theories and models that have conceptualized products as physical artifacts. This intangibility enables the delivery or "exporting" of the products in an electronic mode. In many cases the product itself can be delivered around the world via the Internet by using a firm's file transfer protocol server or by sending it as an attached file of e-mail. In these cases, the choice of entry mode was not relevant for traditional exporting activities. However, choosing an entry mode became important when a firm needed physical presence or a distributor in a country for some specific reason, such as to handle after-sales support, implementation, specifying the 
product with customers etc. This might also be the main reason why the distribution model of a firm was not connected to the choice of entry mode of the case firms.

This research also has some limitations. First, we focused only on business models of firms that have units or representatives of their own in the market. Thus, this study not takes into consideration firms that handle the market solely by using distributors. Further research that also includes those firms could give a wider perspective to the phenomena. Secondly, although the sample of this study was extensive in the context of small Finnish software firms operating in the Japanese market, it is rather small in a wider context. More research is needed to analyze connections between software firms' business models and selected entry modes, for instance, by using a quantitative research method. Thirdly, this study only included the firms' current entry mode in the Japanese market and did not take into consideration the internationalization history of the case firms.

More specific research is needed to examine how software firms enter a particular market and how their entry mode changes or evolves after market entry. The Uppsala internationalization model (Johanson and Wiedersheim-Paul, 1975; Johanson and Vahlne, 1977) could be applied together with firms' business model for the analysis on how a firm's entry mode evolves over the time when it gathers experiential knowledge in the market. Also the influence of business and social networks (Johanson and Mattsson, 1988; Ellis, 2000) on the entry mode beside of a firm's business model requires further research. Finally, as current research suggests (see e.g. Bell et al., 2003; Crick and Spence, 2005; Johanson and Vahlne, 2003; Jones, 1999), internationalization and entry mode selection of SMEs should be studied as a holistic process. Combining the concepts of knowledge, network relationships and the nature of a firm's product offering could create new insight for international entrepreneurship research.

\section{References}

Bakos, Y. and E. Brynjolfsson, 1999, 'Bundling Information Goods: Pricing, Profits, and Efficiency', Management Science 45 (12), 1613-1630.

Bell, J., 1995, 'The Internationalization of Small Computer Software Firms: A Further Challenge to "Stage" Theories', European Journal of Marketing 29 (8), 60-75.

Bell, J., 1997, 'A Comparative Study of the Export Problems of Small Computer Software Exporters in Finland, Ireland and Norway', International Business Review 6 (6), 585-604.

Bell, J., R. McNaughton, S. Young, and D. Crick, 2003, 'Towards an Integrative Model of Firm Internationalization', Journal of International Entrepreneurship 1 (1), 339-362.

Bradley, F. and M. Gannon, 2000, 'Does the Firm's Technology and Marketing Profile Affect Foreign Market Entry?', Journal of International Marketing 8 (4), 12-36.

Brouthers, K.D., 1995, 'The Influence of International Risk on Entry Mode Strategy in the Computer Software Industry', Management International Review 35 (1), 7-28.

Brouthers, K.D., L.E. Brouthers, and S. Werner, 1996, 'Dunning's Eclectic Theory and the Smaller Firm: the Impact of Ownership and Location Advantages on the Choice of EntryModes in the Computer Software Industry', International Business Review 5 (4), 377-394.

Brouthers, K.D. and G. Nakos, 2004, 'SME Entry Mode Choice and Performance: A Transaction Cost Perspective', Entrepreneurship Theory and Practice 28 (3), 229-247.

Brouthers, K.D. and Y.M, Van de Kruis, 1997, 'Competing in Software: Strategies for Europe's Niche Business', Long Range Planning 30 (4), 518-528.

Buckley, P.J. and M. Casson, 1981, 'The Optimal Timing of a Foreign Direct Investment', The Economic Journal 91 (361), 75-87. 
Burgel, O. and G.C. Murray, 2000, 'The International Market Entry Choice of Start-Up Companies in High-Technology Industries', Journal of International Marketing 8 (2), 33-62.

Coviello, N. and H. Munro, 1997, 'Network Relationships and the Internationalisation Process of Small Software Firms', International Business Review 6 (4), 361-386.

Crick, D. and M. Spence, 2005, 'The internationalisation of 'high performing' UK high-tech SMEs: a study of planned and unplanned strategies', International Business Review 14 (2), 167-185.

Currie, W.L., 2004, 'Value creation from the application service provider e-business model: the experience of four firms', Journal of Enterprise Information Management 17 (2), 117-130.

Czinkota, M.R. and M. Kotabe, 2000, 'Entering the Japanese Market: A Reassessment of Foreign Firms' Entry and Distribution Strategies', Industrial Marketing Management 29 (6), 483-491

Dunning, J.H., 1988, 'The Eclectic Paradigm of International Production: A Restatement and Some Possible Extensions', Journal of International Business Studies 19 (1), 1-31.

Eisenhardt, K.M., 1989, 'Building Theories from Case Study Research', Academy of Management Review 14 (4), 532-550.

Ellis, P., 2000, 'Social Ties and Foreign Market Entry', Journal of International Business Studies, 31 (3), 443-469.

Hoch, D., C. Roeding, G. Purkert, S. Lindner, and R. Müller, 2000, Secrets of Software Success: Management Insights from 100 Software Firms Around the World, USA: Harvard Business School Press.

Jain, S. and P.K. Kannan, 2002, 'Pricing of Information Products on Online Servers: Issues, Models, and Analysis', Management Science 48 (9), 1123-1142.

Johanson, J. and L-G. Mattsson, 1988, 'Internationalisation in Industrial Systems - A Network Approach' in N. Hood and J-E. Vahlne (eds.), Strategies in Global Competition, London: Croom Helm, pp. 287-314.

Johanson, J. and J-E. Vahlne, 1977, 'The internationalization process of the firm - a model of knowledge development and increasing foreign market commitments', Journal of International Business Studies 8 (1), 23-32.

Johanson, J. and J-E. Vahlne, 2003, 'Business Relationship Learning and Commitment in the Internationalization process', Journal of International Entrepreneurship 1 (1), 83-101.

Johanson, J. and F. Wiedersheim-Paul, 1975, 'The internationalization of the firm: four Swedish cases', Journal of Management Studies 12 (3), 305-322.

Jones, M.V., 1999, 'The Internationalization of Small High-Technology Firms', Journal of International Marketing 7 (4), 15-41.

Kontio, J., J-P. Jokinen, M.M. Mäkelä, and V. Leino, 2005, 'Current Practices and Research Opportunities in Software Business Models', Proceedings of the $7^{\text {th }}$ International Workshop on Economics-Driven Software Engineering Research, St. Louis, USA.

Lu, J.W. and P.W. Beamish, 2001, 'The Internationalization and Performance of SMEs', Strategic Management Journal 22 (6-7), 565-585.

Luostarinen, R., 1979, The Internationalization of the Firm. Doctoral thesis, A: 30, Helsinki School of Economics: Finland.

Luostarinen, R. and L. Welch, 1997, International Business Operations. Finland: Kyriiri Oy.

Magretta, J., 2002, 'Why Business Models Matter', Harvard Business Review 80 (5), 86-92.

Mahadevan, B., 2000, 'Business Models for Internet-Based E-Commerce: An Anatomy', California Management Review 42 (4), 55-69.

McNaughton, R.B., 1996, 'Foreign Market Channel Integration Decisions of Canadian Computer Software Firms', International Business Review 5 (1), 23-52. 
Miles, M.B. and A.M. Huberman, 1994, Qualitative Data Analysis: An Expanded Sourcebook. California: Sage Publications.

Moen, O., M. Gavlen, and I. Endresen, 2004, 'Internationalization of small, computer software firms: Entry forms and market selection', European Journal of Marketing 38 (9/10), 12361251.

Nakos, G. and K.D. Brouthers, 2002, 'Entry Mode Choice of SMEs in Central and Eastern Europe', Entrepreneurship Theory and Practice 27 (1), 47-63.

Rajala, R., M. Rossi, and V.K., Tuunainen, 2003a, 'A Framework for Analyzing Software Business Models', Proceedings of the $11^{\text {th }}$ European Conference on Information Systems, Naples, Italy.

Rajala, R., M. Rossi, and V.K. Tuunainen, 2003b, 'Software Vendor's Business Model Dynamics Case: TradeSys', Annals of Cases on Information Technology 5 (1), 538-548.

Rajala, R., M. Westerlund, A. Rajala, and S. Leminen, 2004, Business Models and Value Nets as the Context of Knowledge Intensive Service Activities in the Software Business, LTT Research LTD, Series B 170, Helsinki, Finland.

Tikkanen, H., J-A. Lamberg, P. Parvinen, and J-P. Kallunki, 2005, 'Managerial cognition, action and the business model of the firm', Management Decision 43 (6), 789-809.

Williamson, O., 1985, The Economic Institutions of Capitalism. The Free Press, New York. Yin, R.K., 1994, Case Study Research: Design and Methods. California: SAGE Publications. Zeng, M. and W. Reinartz, 2003, 'Beyond Online Search: The Road to Profitability', California Management Review 45 (2), 107-130. 